French science

\section{Old guard takes high jump}

IN a week of long knives, the new rightwing government of France has removed three of the old guard in charge of the major scientific institutions. The development is to say the least surprising, coming as it does just a few weeks before the council of ministers has to decide the distribution of a FF40,000 million $(£ 4,000$ million) cut in overall government spending.

Last Wednesday, Pierre Papon, director-general of the Centre National de la Recherche Scientifique (CNRS), with its 20,000 staff and budget of FF 9,000 million ( 900 million), was sacked. Independently, Jean-Jacques Payan, in charge of the universities, and Bernard Descompes, who had introduced innovative new funding structures designed to improve university research, resigned.

The sacking of the CNRS directorgeneral, who was re-appointed by presidential decree for a three-year term only last December, is unprecedented. Papon had been a key figure in the development of the previous administration's policy on science, and his removal may be symbolic of the new government's determination to have its way. Usually (as with Payan and Descompes) the government is content to provoke the resignation of those among its senior officials with whom it is out of sympathy.

Papon seems to have been determined to hold on to protect the considerable achievements of the old regime, and had been planning in September to present a package of policies designed to achieve that to the new science minister, Alain Devaquet. But the new government seemed unable to wait.

Nevertheless, Papon's replacement should not cause too many shudders in the scientific community, at least if he inherits some of his predecessor's power. The new man, Serge Feneuille, is a reputed physicist who for five years has been chief scientist of the cement makers La Farge Coppée, a company which with Feneuille's help had begun to diversify and take an interest in biotechnology.

Despite the pre-election pressure from the right to dismantle the vast and interdisciplinary CNRS, the feeling at the research council, where Feneuille has worked before, is that he will "protect" the institution. With his background, he should also be interested in continuing to forge links between the scientific community, industry and the public in line with the previous administration's policy.

Such doubts as there are arise because of the government's budget-cutting mood and the apparent political weakness of the research minister Alain Devaquet, a man whom most scientists are willing to em- brace as an ally against a larger foe, the finance ministry, which has emerged as the main instrument of Prime Minister Chirac's political philosophy. The outlook for research spending in France looks bleak, with a new CNRS director-general reporting to a minister already in a weak political position and with major budget decisions due in July.

Sacked Papon spoke last week of the need to maintain the integrity of CNRS, and especially, the momentum of the interdisciplinary programmes on which he spent much of his effort. "Feudalities are a permanent temptation in France", Papon said.

$\mathrm{He}$ is also anxious that the policy of cooperation between universities and industry should be maintained. "The end of the Ministry of Research and Technology was a mistake", says Papon, because of the separation of "responsibilities for science and technology" which is implied. If the ministry is not strong, "it will be the end of the coherence of the whole programme".

Robert Walgate

\title{
Another new White House man
}

Washington

President Ronald Reagan last week nominated William R. Graham, deputy administrator of the National Aeronautics and Space Administration (NASA), as his science adviser and director of the White

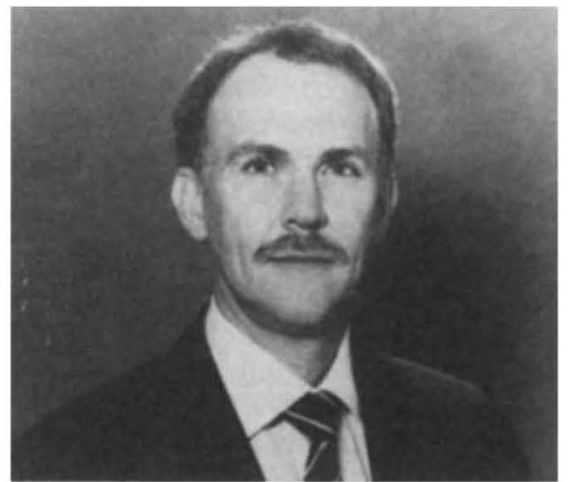

House's Office of Science and Technology Policy (OSTP). The twin posts had been without a permanent occupant for the past 6 months, since George A. Keyworth II resigned in December to form a private consulting company. The acting director of OSTP since the start of the year, John McTague, resigned two weeks ago to take a position in industry.

The six-month delay in finding a replacement for Keyworth has provoked criticism from the scientific community. Several potential candidates have turned down offers, and many observers felt the difficulty in finding a permanent incumbent was indicative of the diminishing influence of OSTP in the White House. Several other senior OSTP officials have resigned in recent months without being replaced, and the office's proposed budget for 1987 is a hefty cut from this year's level.

Graham's nomination has therefore been greeted with subdued relief by scientific leaders, but some express reservations that his military background and advocacy of the militarization of space made him a less than ideal candidate. Robert Park of the American Physical Society said that the appointment was consistent with Reagan's previous appointments of "technocrats" to the post, rather than of distinguished academic scholars.

William Carey, executive officer of the American Association for the Advancement of Science, who had been vocal in his criticism of the hiatus at OSTP, said he was glad someone was now in place who was familiar with high-technology initiatives. But he admitted to being concerned that Graham's background might lead him to offer advice on investment decisions that would be "tilted in one direction". Asked specifically about Graham's known support for the Strategic Defense Initiative, Carey responded "what's new?". Keyworth was also a staunch defender of the programme.

Graham first came to public attention last year when he stepped in to become acting administrator of NASA after the indictment on fraud charges of NASA's former administrator, James Beggs. With the appointment in May of James Fletcher as permanent NASA administrator, Graham needed somewhere to go, as Fletcher had no special desire to keep Graham on as his deputy. Graham's appointment will need confirmation by the Senate, but because his appointment at NASA was also the subject of a confirmation hearing, no serious opposition is expected.

Before going to NASA, Graham was chairman of the general advisory committee of the Arms Control and Disarmament Agency. He started his career as a research physicist at Stanford University, and subsequently worked on survivability of strategic systems for the Air Force and a National Research Council study of submarine warfare. In 1971 he formed a consulting company, R\&D Associates, and he has frequently been a consultant for the Department of Defense. But there was some criticism of his performance at NASA during the admittedly turbulent period of his office as acting administrator.

Tim Beardsley 